\title{
Comparison of eight methods of genomic DNA extraction from babassu
}

\author{
J.P.G. Viana', A.N.C. Borges ${ }^{2}$, A.C.A. Lopes ${ }^{3}$, R.L.F. Gomes ${ }^{3}$, F.B. Britto', \\ P.S.C. Lima ${ }^{4}$ and S.E.S. Valente ${ }^{2}$ \\ ${ }^{1}$ Programa de Pós-Graduação em Genética e Biologia Molecular, \\ Universidade Estadual de Campinas, Campinas, SP, Brasil \\ 2Departamento de Biologia, Universidade Federal do Piauí, Campus Ininga, \\ Teresina, PI, Brasil \\ ${ }^{3}$ Departamento de Agronomia, Universidade Federal do Piauí, Campus Ininga, \\ Teresina, PI, Brasil \\ ${ }^{4}$ Empresa Brasileira de Pesquisa Agropecuária, EMBRAPA Meio-Norte, \\ Teresina, PI, Brasil \\ Corresponding author: S.E.S. Valente \\ E-mail: svalente@ufpi.edu.br \\ Genet. Mol. Res. 14 (4): 18003-18008 (2015) \\ Received September 23, 2015 \\ Accepted November 19, 2015 \\ Published December 22, 2015 \\ DOI http://dx.doi.org/10.4238/2015.December.22.26
}

\begin{abstract}
Babassu (Orbignya phalerata Martius) is one of the most important palms in Brazil because of the largest morphological variation, wide geographic distribution, and high socio-economic importance. The diversity present in babassu germplasm should be protected against loss to ensure their use with high productivity. Study of the available variability in populations of babassu is necessary to develop conservation strategies. The study of genetic variability can be conducted using molecular markers and many of these studies require significant quantity of high-quality DNA. The present study aimed to effect comparison among eight DNA extraction methods in case of $O$. phalerata. The quality and concentration of nucleic acids were analyzed by spectrophotometry and integrity of DNA was ascertained by agarose gel electrophoresis. The spectrophotometry revealed that some methods resulted in high levels of concentration of nucleic acids,
\end{abstract}


in which values of the ratio $A_{260 / 280}$ and $A_{260 / 230}$ were outside the range of purity. The agarose gel electrophoresis established the concentration and integrity of DNA. The methods of Murray and Thompson (1980) and Ferreira and Grattapaglia (1998) did not result in satisfactory quantities of DNA. Conversely, the method proposed by Khanuja et al. (1999) resulted in DNA of adequate quality and quantity that could be satisfactorily used for amplification reactions performed with two ISSR primers.

Key words: Genetic resources; Genetic variability; Germplasm; Orbignya phalerata

\section{INTRODUCTION}

Babassu (Orbignya phalerata) is a palm tree native to the Northeast, North, and Midwest of Brazil. It has highest occurrence, in terms of the area planted in the Brazilian Northeast region (Castro et al., 2002). This region has the highest distribution and the greatest morphological variation of babassu (Rufino et al., 2008). Babassu has the potential for the production of biodiesel and can be used as an alternative to non-renewable sources of energy, such as oil, charcoal, and natural gas (Lima et al., 2007).

Germplasm of any species should be protected from eventual genetic losses by means of breeding programs to ensure its sustainable use (Vieira, 2006). The development of genetic conservation strategies for a species includes the study of the distribution of genetic variability within and among its populations (Lacerda and Kageyama, 2003). Advances in molecular biology have provided several new methods for the genetic studies of natural populations (Silveira et al., 2009).

The genetic diversity characterization of a plant species involves the study of a large number of individuals along with the use of rapid and accurate methods of DNA extraction (Molinari and Crochemore, 2001). There are several different protocols for DNA extraction that enable researchers to focus on variations in the biochemical composition among plant species. These protocols yield DNA of sufficient quality and quantity to be used in plant molecular studies (Sousa et al., 2014). It is known that contamination of the isolated DNA by polysaccharides, phenols, and secondary compounds can damage the DNA, inhibit the action of restriction enzymes, and cause interference in migration patterns on gel electrophoresis (Romano and Brasileiro, 1999).

Considering the necessity to obtain DNA that meets the requirements of various molecular biology experiments, we aimed to evaluate eight protocols for genomic DNA extraction in $O$. phalerata for the purity and concentration of the DNA extracted.

\section{MATERIAL AND METHODS}

Leaf tissue was collected from individuals of $O$. phalerata from the Centro de Ciências Agrárias (CCA)/Universidade Federal do Piauí (UFPI), located in Teresina, Piauí, Brazil.

For the experiments, young leaf tissue free from ectoparasites and epibiotic organisms were selected. Leaves were wrapped in paper towels, kept in plastic bags, placed in styrofoam boxes filled with ice, and taken to the laboratory, where the extractions were performed.

Eight protocols, namely those described by Murray and Thompson (1980), Dellaporta et al. (1983), Doyle and Doyle (1987), Ferreira and Grattapaglia (1998), Romano and Brasileiro (1999), Khanuja et al. (1999), Warude et al. (2003), and Khan et al. (2004) were analyzed, according to the 
original recommendations, with modifications to adapt to the amount of leaf tissue used. In each sample, the DNA was extracted from $100 \mathrm{mg}$ fresh leaf tissue and macerated in liquid nitrogen. After the extraction, all the samples were diluted in $100 \mu \mathrm{L}$ TE buffer (1 mM EDTA, $10 \mathrm{mM}$ Tris$\mathrm{HCl}, \mathrm{pH}$ 8.0). Reagents and their concentrations, specific to each extraction, were prepared as described in the respective protocols.

Nucleic acids obtained by the extractions, were quantified and their purity was examined on a spectrophotometer (NanoDrop $\left.{ }^{\circledR} 2000-2000 C\right)$, using $1 \mu \mathrm{L}$ sample. Quality of the samples was estimated by measuring the ratios $A_{260 / 280}$ (DNA concentration relative to proteins) and $A_{260 / 230}$ (DNA concentration relative to secondary metabolites and buffer components). The samples with $A_{260 / 280}$ and $A_{260 / 230}$ values in the ranges 1.8-2.0 and 2.0-2.2, respectively, were classified as pure. Determination of the integrity and concentration of DNA samples, to exclude impurities and other nucleic acids that contribute to the values obtained in the spectrophotometry, was performed by electrophoresis on $0.8 \%$ agarose gel, using the intercalating agent GelRed ${ }^{\mathrm{TM}} 10000 \mathrm{X}$ (Uniscience, USA) with the Bromophenol Blue as carrier, visualized under ultraviolet light (UV) and photographed. For DNA quantification $5 \mu \mathrm{L}$ samples and DNA marker (phage $\lambda$ ) with concentration $100 \mathrm{ng} / \mu \mathrm{L}$ were used.

Polymerase chain reaction (PCR) amplifications were performed in a Veriti 96-Well Thermal Cycler (Applied Biosystems ${ }^{\circledR}$, USA) with an initial denaturation step of $90 \mathrm{~s}$ at $94^{\circ} \mathrm{C}$; 35 cycles of $40 \mathrm{~s}$ at $94^{\circ} \mathrm{C}$ (denaturation), $45 \mathrm{~s}$ at $50^{\circ} \mathrm{C}$ (UBC845 annealing) or $55^{\circ} \mathrm{C}$ (UBC856 annealing), and 2 min at $72^{\circ} \mathrm{C}$; and a final extension of $7 \mathrm{~min}$ at $72^{\circ} \mathrm{C}$. The two inter-simple sequence repeat (ISSR) primers UBC845 (5'-CTC TCT CTC TCT CTC TRG-3') and UBC856 (5'-ACA CAC ACA CAC ACA CYA-3') were obtained from University of British Columbia, Canada. The reaction mix contained $1 \mu \mathrm{L}$ DNA (7 ng/ $\mu \mathrm{L}), 0.8 \mathrm{mM}$ dNTP (dATP, dCTP, dGTP, and dTTP), $1 \mathrm{U}$ Taq DNA polymerase (Invitrogen), $0.8 \mathrm{mM}$ primer, $2.0 \mathrm{mM} \mathrm{MgCl}, 2.0 \mu \mathrm{L} 1 \mathrm{X}$ buffer [20 mM Tris-HCl, $\mathrm{pH}$ 8,0; $0.1 \mathrm{mM}$ EDTA; $1 \mathrm{mM}$ DTT; $50 \%$ (v/v) glycerol] and ultrapure $\mathrm{H}_{2} \mathrm{O}$ in a $10-\mu \mathrm{L}$ final volume. The amplification products were separated on a $1.5 \%$ agarose gel in $0.5 \mathrm{X}$ TBE buffer and the gels were stained with GelRed $^{\text {TM }} 10,000 X$ (Uniscience). The sizes of the amplified fragments were determined based on 100-bp DNA ladder (Invitrogen, Thermo Fisher Scientific Corporation, USA), and the products were visualized on an ultraviolet transilluminator and documented.

\section{RESULTS AND DISCUSSION}

The average concentrations and purity $\left(A_{260 / 280}\right.$ and $\left.A_{260 / 230}\right)$ of the DNA extracted from the leaves of $O$. phalerata by the eight methods are shown in Table 1. Of the tested protocols, we wanted to determine which protocol yielded DNA of the best quality and greatest quantity.

\begin{tabular}{|c|c|c|c|c|}
\hline Protocol & Concentration $(\mathrm{ng} / \mu \mathrm{L})^{1}$ & $\mathrm{~A}_{260 / 280}$ ratio & $\mathrm{A}_{260 / 230}$ ratio & Concentration $(\mathrm{ng} / \mu \mathrm{L})^{2}$ \\
\hline Murray and Thompson (1980) & 19.78 & 1.51 & 0.33 & 0.0 \\
\hline Dellaporta et al. (1983) & 70.10 & 1.63 & 0.69 & 8.1 \\
\hline Doyle and Doyle (1987) & 111.79 & 1.78 & 0.98 & 30.0 \\
\hline Ferreira and Grattapaglia (1998) & 36.56 & 1.50 & 0.50 & 2.5 \\
\hline Romano and Brasileiro (1998) & 97.10 & 1.78 & 0.93 & 29.3 \\
\hline Khanuja et al. (1999) & 26.57 & 2.04 & 1.99 & 20.6 \\
\hline Warude et al. (2003) & 156.51 & 1.46 & 0.63 & 47.5 \\
\hline Khan et al. (2004) & 180.83 & 1.42 & 0.34 & 16.6 \\
\hline
\end{tabular}

${ }^{1}$ Concentration of nucleic acids, estimated through quantification by spectrophotometry. ${ }^{2}$ DNA estimated through electrophoresis on $0.8 \%$ agarose gel and comparing to $100 \mathrm{ng} / \mu \mathrm{L}$ DNA marker (phage $\lambda$ ). 
Spectrophotometry indicates that the methods described by Warude et al. (2003) and Khan et al. (2004) showed high levels of concentration of nucleic acids; however, the $A_{260 / 280}$ and $A_{260 / 230}$ ratios are outside the boundaries adopted as purity standards for the samples. The method described by Doyle and Doyle (1987), resulted in high average concentration of nucleic acid (104.0 $\mathrm{ng} / \mu \mathrm{L})$. The $A_{260 / 280}$ ratio suggests that samples were not contaminated. Measurement of $A_{260 / 230}$ is an alternative approach to assess the DNA purity when the value of the ratio $A_{260 / 280}$ is outside the range that describes the purity of DNA. The mean ratio $A_{260 / 230}$ was lower than the range of the values assigned for pure samples, which is an indication that the sample may be contaminated with buffering reagents. The method described by Khan et al. (2004) was effective to obtain high concentrations of nucleic acids (mean $=180.83 \mathrm{ng} / \mu \mathrm{L}$ ) as indicated by the quantification by spectrophotometry. However, the average numerical value of the ratio $A_{260 / 280}$ for the samples was 1.42 , which is not within the range that could classify the DNA as "pure". In addition, purity of the samples appeared to be further compromised as the ratio $A_{260 / 230}$ of the samples, the average value of which was 0.34 , was well below the optimal range. Two other methods, i.e., the protocol described by Warude et al. (2003) and that described by Romano and Brasileiro (1999) resulted in good DNA concentrations, as observed by the quantification by spectrophotometry; however, the DNA quality resulting from applying the method of Warude et al. (2003) was not satisfactory since the $A_{260 / 280}$ ratio values are below the optimal range, indicating contamination by proteins. The protocol described by Khanuja et al. (1999) has resulted in the average DNA concentration 26.57 $\mathrm{ng} / \mathrm{\mu L}$, moreover, the method demonstrated the best purity ratios among the protocols tested, resulting in the numerical values 2.04 and 1.99 for $A_{260 / 280}$ and $A_{260 / 230}$, respectively.

The integrity and concentration of DNA was confirmed by electrophoresing the samples $(4 \mu \mathrm{L}$ each) on agarose gel and observing under UV light. The electrophoresis revealed that the method described by Murray and Thompson (1980) showed no DNA in the samples (Figure 1). Thus, the nucleic acids present in the spectrophotometry of the samples corresponding to this protocol were RNA. This was possibly because none of the methods included RNAse treatment steps. Murray and Thompson (1980) reported that often some residual RNA is co-isolated in DNA extractions, which can be removed by treatment with RNAse. However, they described that the presence of residual RNA has not influenced the PCR or the studies with restriction enzymes and the RNase treatment may be unnecessary.

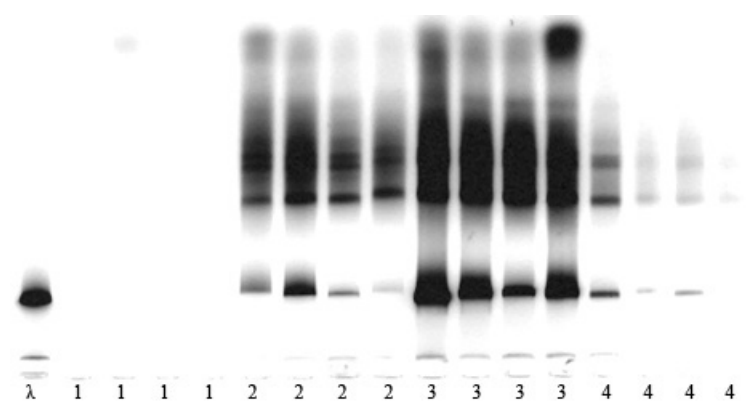

Figure 1. Electrophoretic profile of DNA extracted from young leaves of Orbignya phalerata by the following methods: 1 - Murray and Thompson (1980; lanes 2, 3, 4, 5); 2 - Dellaporta et al. (1983; lanes 6, 7, 8, 9); 3 - Doyle and Doyle (1987; lanes 10, 11, 12, 13); and 4 - Ferreira and Grattapaglia (1998; lanes 14, 15, 16, and 17).

The method proposed by Dellaporta et al. (1983) yielded low DNA concentrations; in addition, it resulted in degradation. Similarly, the method described by Ferreira and Grattapaglia 
(1998) demonstrated low concentration of partially degraded DNA. The method described by Doyle and Doyle (1987), as observed from the measurement on agarose gel revealed that the method resulted in high DNA concentrations, but DNA was partially degraded; therefore, DNA isolation by this method was not suitable for experiments requiring high-quality DNA of O. phalerata (Figure 1).

The methods described by Warude et al. (2003) and Romano and Brasileiro (1999) achieved higher DNA concentrations with low levels of degradation (Figure 2). The protocol described by Khan et al. (2004), exhibited high concentrations of nucleic acids in the quantification by spectrophotometry, but low DNA concentrations were observed by quantification on agarose gel.

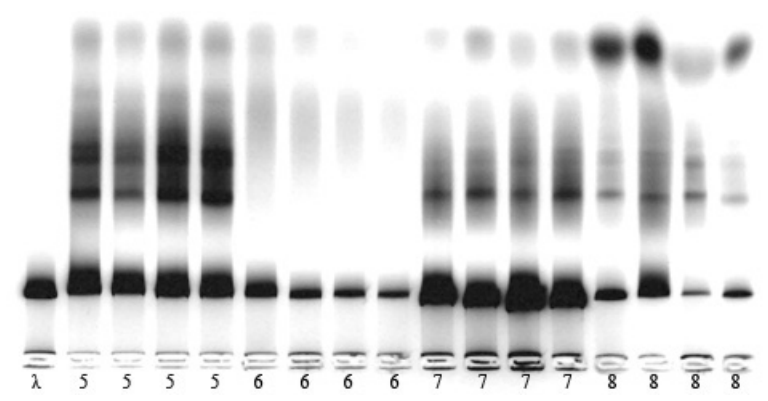

Figure 2. Electrophoretic profile of the DNA extracted from young leaves of Orbignya phalerata by the following methods: 5 - Romano and Brasileiro (1998; lanes 2, 3, 4, 5); 6 - Khanuja et al. (1999; lanes 6, 7, 8, 9); 7 - Warude et al. (2003; lanes 10, 11, 12, 13); and 8 - Khan et al. (2004; lanes 14, 15, 16, and 17). Lane 1 contained $100 \mathrm{ng} / \mathrm{\mu L}$ DNA marker (phage $\lambda$ ).

The quantification of samples subjected to the method described by Khanuja et al. (1999), on agarose gel corroborated the results found by spectrophotometry. Together both the analytical methods confirmed the isolation of intact and high-quality DNA, recommended for experiments requiring high-quality DNA (Figure 2). The protocol of Khanuja et al. (1999) is effective for DNA isolation from plant parts with high content of essential oils and secondary metabolites, for example, babassu leaves.

The amplification reactions performed with two ISSR primers evinced good resolution indicating that the amount and quality of the DNA extracted by the protocol described by Khanuja et al. (1999) were adequate for performing PCR and could be utilized in molecular biology studies in the future (Figure 3).

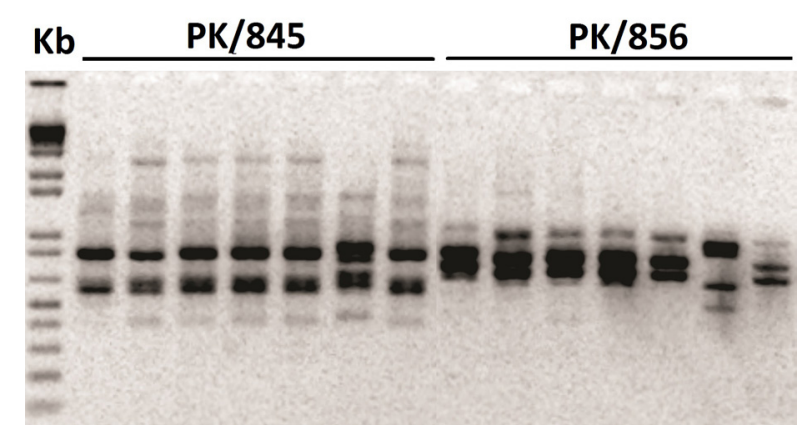

Figure 3. Electrophoretic profile of the products of the PCR performed using ISSR primers UBC 845 and UBC 856 and the DNA extracted from young leaves of Orbignya phalerata by the method described by Khanuja et al. (1999). 
Thus, due to the better resolution demonstrated in the electrophoretic profile on agarose gel quantification and in the amplification reactions performed with two ISSR primers, we recommend the use of the method of Khanuja et al. (1999) for DNA extraction from babassu leaves in the conditions in which this study was performed.

\section{Conflicts of interest}

The authors declare no conflict of interest.

\section{ACKNOWLEDGMENTS}

We are thankful to EMBRAPA, Teresina, PI, Brazil, for the space assigned to perform the experiments and CAPES (Agency for Graduate Training - Brasília, DF, Brazil) for financial support.

\section{REFERENCES}

Castro AAC, Braga MED and Mata MERMC (2002). Comportamento ecológico do azeite de coco de babaçu em diferentes temperaturas. Rev. Bras. Oleaginosas Fibrosas 6: 459-463.

Dellaporta SL, Wood J and Hicks JB (1983). A plant minipreparation: version II. Plant Mol. Biol. Rep. 1: 19-20.

Doyle JJ and Doyle JL (1987). A rapid DNA isolation procedure for small quantities of fresh leaf tissue. Phytochem. Bull. 19: 11-15.

Ferreira ME and Grattapaglia D (1998). Introdução ao uso de marcadores moleculares em análise genética. 3rd edn. Embrapa, Cenargen, Brasília.

Khan IA, Awan, FS, Ahmad A and Khan AA (2004). A modified mini-prep method for economical and rapid extraction of genomic DNA in plants. Plant Mol. Biol. Rep. 22: 89-89.

Khanuja SPS, Shasany AK, Darokar MP and Kumar S (1999). Rapid isolation of DNA from dry and fresh samples of plants producing large amounts of secondary metabolites and essential oils. Plant Mol. Biol. Rep. 17: 74-74.

Lacerda CMB and Kageyama PY (2003). Estrutura genética de duas populações naturais de Myracrodruon urundeuva M. Allemão na região semi-árida, Brasil. Rev. Árvore 27: 145-150.

Lima JRO, Silva RB, Silva CCM, Santos LSS, et al. (2007). Biodiesel de babaçu (Orbignya sp.) obtido por via etanólica. Quím. Nova 30: 600-603.

Molinari HB and Crochemore ML (2001). Extração de DNA genômico de Passiflora spp. para análises PCR-RAPD. Rev. Bras. Frutic. 23: 447-450.

Murray MG and Thompson WF (1980). Rapid isolation of high molecular weight plant DNA. Nucleic Acids Res. 8: 4321-4325.

Romano E and Brasileiro ACM (1999). Extração de DNA de plantas. Biotecnol. Cienc. Desenvolv. 2: 40-43.

Rufino MUL, Costa JTM, Silva VA and Andrade LHC (2008). Conhecimento e uso do ouricuri (Syagrus coronata) e do babaçu (Orbignya phalerata) em Buíque, PE, Brasil. Acta Bot. Bras. 22: 1141-1149.

Silveira DG, Amorim EP, Jesus ON, Souza FVD, et al. (2009). Variabilidade genética de populações naturais de caroá por meio de marcadores RAPD. Pesq. Agropec. Bras. 44: 283-290.

Sousa CC, Gomes SO, Lopes AC, Gomes RL, et al. (2014). Comparison of methods to isolate DNA from Caesalpinia ferrea. Genet. Mol. Res. 13: 4486-4493.

Vieira MLC (2006). Conservação de germoplasma in vitro. Biotecnol. Cienc. Desenvolv. 14:18-20.

Warude D, Chavan P, Joshi K and Patwardhan B (2003). DNA Isolation from fresh, dry plant samples with highly acidic tissue extracts. Plant Mol. Biol. Rep. 21: 467-467. 